\title{
A Study on Relationship between Internet Banking Portal Service Quality and Customer Satisfaction towards the Bank
}

\author{
Dr. Nirav B. Halvadia \\ (Associate Professor, St. Kabir Institute of Professional Studies, Ahmedabad, Gujarat) \\ Dr. ShekhaHalvadia \\ (Faculty, Kadi Sarva Vishwavidyalaya, Gujarat)
}

\begin{abstract}
:
Service quality is one of the major determinants of consumer satisfaction. For maintaining and expanding the bank customer base, banks must understand the relationship between overall internet banking portal service quality, and satisfaction with banking overall. So, it is important to study the relationship between internet banking portal service quality and customer overall satisfaction towards the bank.

This study investigates the impacts of overall internet banking portal service quality on customer satisfaction towards the bank. Data for the research was collected from a sample of 400 bank customers of some selected Indian public and private banks who use internet banking portal. The reliable and valid instrument confirmed in this research can be used by further studies detecting the relationships among these constructs in an extended context.
\end{abstract}

Keywords: E-commerce, online service quality, SEM, internet banking.

\section{Introduction:}

More and more banks have adopted technology to deliver their services and this has resulted in: reduced costs, the creation of value-added services for customers (Zhu et al., 2002), the facilitation of their employees' job and ultimately the provision of self-service option for customers (Dabholkar \&Bagozzi 2002). The concept of banking has drastically changed where technology is the most dominating factor which helped banks to have a mixed knowledge with innovative products/services to win the competitive market. As far as retail banks are concerned, the introduction of internet banking has brought a dramatic change in a way relationships with the customers are built and maintained. 
Internet banking portal means that all stages of the financial transactions can be processed electronically. This is achieved by replacing personal interaction and physical facilities with technological solutions. As a consequence, customers can carry out different financial transactions at one site including paying bills, booking railway and air tickets, charging mobile phone and TV, donating money, paying tax, filing the tax return, viewing bank statements, purchasing stocks and other financial products (e.g. insurance), etc...Thus, internet banking portals transfer the "all in one" principle from the old economy-to the internet (Bauer and Hammerschmidt, 2002; Jun and Cai, 2001). In e-banking services, one of the important technological innovations is the internet banking portal.Today, most of all Indian public, private and foreign banks have their internet banking portal.

Recently, in the information system area, some researches began to try to investigate the relationship between web site quality and customer satisfaction. For example, in a study of electronic commerce channel preference, Devaraj et al. (2002) also showed that service quality is

one of the major determinants of consumer satisfaction. Internet banking portal service quality and their satisfaction with the bank overall is still a relatively new area (Jayawardhena, 2004; Sohail and Shaikh, 2008). For maintaining and expanding bank customer base, banks must understand the criteria consumers use to evaluate internet banking portal services and how these impact on their perceptions of overall internet banking portal service quality, and satisfaction with banking overall (Rod et al.,2009). So, it is important to study the relationship between internet banking portal service quality and customer overall satisfaction towards the bank.

\section{Objectives of the Study:}

1. To develop a valid scale for measuring overall internet banking postal service quality and customer satisfaction towards the bank.

2. To study the impact of overall internet banking postal service quality on customer satisfaction towards the bank.

\section{Literature Review on Relationship between Overall Internet Banking Portal Service Quality and Customers Overall Satisfaction towards the Bank:}

End-user satisfaction is an important area of information system research because it is considered a significant factor in measuring information research success and use (Ives and Olson, 1984; Halvadia and Patel, 2019).

Recently, in the information system area, some researches began to try to investigate the relationship between web site quality and customer satisfaction. For example, McKinney et al. (2002) found that Web-customer satisfaction is determined by the nine quality-related constructs. In a study of electronic commerce channel preference, Devaraj et al. (2002) also showed that 
service quality is one of the major determinants of consumer satisfaction. Internet banking service quality and their satisfaction with the bank overall is still a relatively new area (Jayawardhena, 2004; Sohail and Shaikh, 2008).

For maintaining and expanding the bank customer base, banks must understand the criteria consumers use to evaluate internet banking services and how these impact on their perception of overall internet banking service quality, and satisfaction with e-service and banking overall (Rod et al.,2009).

Studies carried out in a variety of countries illustrate that internet banking service quality influences customer satisfaction with banking overall (Curry and Penman, 2004; Partricio et al., 2003; Yang and Fang, 2004).

Han and Baek (2004) explored the relationships among customer satisfaction, customer retention, and service quality and found a positive relationship between the level of internet banking service quality and customer satisfaction.

Moreover, Yang et al. (2005) found that the overall portal quality had a positive, significant influence on user satisfaction. Kuo et al. (2005) also found out a positive relationship between portal service quality factors and overall satisfaction. This leads to the following hypothesis:

H1: There is an impact of internet banking portal service quality on customers' overall satisfaction towards the bank.

\section{Research Methodology:}

This empirical study was conducted in Gujarat State, India from April to August, 2019. The population of the study was bank customers who were using the internet banking portal of selected Indian public and private sector banks in four large cities (Ahmedabad, Baroda, Surat, and Rajkot) of Gujarat state, India. For the study, we included only the top five public and private sector banks for two reasons. First, these companies contributed significantly in terms of total revenue and market share of the Indian banking sector. And, second, these banks had well-established internet banking portal facilities. The list of the top 5 Indian public and private sector banks are shown in Table 1. 
Table 1. Top five Indian public and private sector banks

\begin{tabular}{|l|l|l|l|}
\hline \multicolumn{1}{|c|}{$\begin{array}{c}\text { Top Five } \\
\text { Indian Public } \\
\text { Sector Banks }\end{array}$} & \multicolumn{1}{|c|}{$\begin{array}{c}\text { Net Profit in } \\
\text { Cr. } \\
\text { Rupees }\end{array}$} & $\begin{array}{c}\text { Top Five Indian } \\
\text { Private Sector } \\
\text { Banks }\end{array}$ & \multicolumn{1}{c|}{$\begin{array}{c}\text { Net Profit in Cr. } \\
\text { Rupees }\end{array}$} \\
\hline $\begin{array}{l}\text { State Bank of } \\
\text { India }\end{array}$ & 11707.29 & ICICI Bank Ltd. & 6466.50 \\
\hline $\begin{array}{l}\text { Bank of } \\
\text { Baroda }\end{array}$ & 5006.96 & HDFC Bank Ltd. & 5167.07 \\
\hline $\begin{array}{l}\text { Punjab } \\
\text { National Bank }\end{array}$ & 4879.95 & Axis Bank Ltd. & 4229.19 \\
\hline Canara Bank & 3281.71 & $\begin{array}{l}\text { Kotak Mahindra } \\
\text { Bank Ltd. }\end{array}$ & 1085.05 \\
\hline Bank of India & 2677.50 & Yes Bank Ltd. & 976.99 \\
\hline
\end{tabular}

Source: Capitaline-Corporate Database

In this study, the total target population was unknown and a sampling frame was not available, so the non-probability sampling technique was adopted. Judgmental sampling, a form of convenience sampling, was used to identify respondents for the study because the researcher judged that a maximum number of internet banking portal users of the selected banks were easily assessable from the selected banks' branches.

To ensure that the questionnaires were completed by relevant respondents, a filter question was asked at the beginning of the questionnaire to determine whether a respondent was using an internet banking portal of the selected Indian public and private sector banks.

\section{Data Analysis:}

Structural Equation Modeling was used to assess the direct impact of overall internet banking portal service quality on customer satisfaction towards banks. Figure 1 shows the path diagram between overall internet banking portal service quality and customers' overall satisfaction toward the bank. 


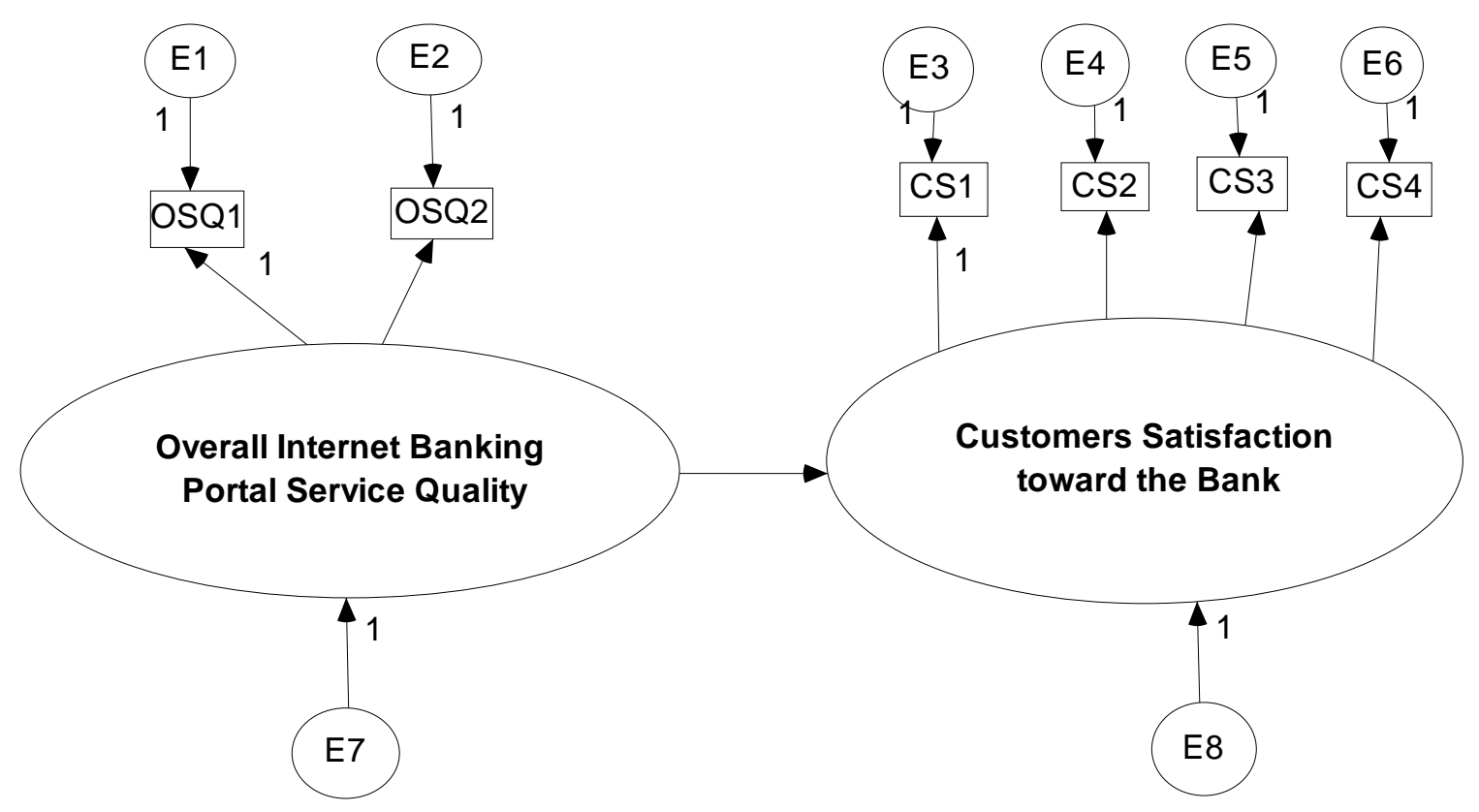

Figure 1: Path Diagram - Impact of Overall Internet Banking Portal Service Quality on Customers Satisfaction toward the Bank

\section{Model Fit:}

Tucker Lewis Index (TLI) value and Comparative Fit Index value (CFI) were used to check the model fit of the model which shows the impact of overall internet banking portal service quality on customers' overall satisfaction towards the bank.

As per Hair et al. (2007), Tucker Lewis Index (TLI) value and Comparative Fit Index value (CFI) near 0.9 indicates a good model fit. The TLI and CFI values for this model were 0.954 and 0.879 respectively and both were near to 0.9 indicates a good model fit.

\section{Assessment of Reliability:}

Reliability was gauged via the standardized Cronbach's alpha coefficient (Cronbach, 1951). Hair et al. (2007) recommended that 0.6 Cronbach's alpha value is deemed the lower limit of acceptability. The final Cronbach's alpha coefficients of overall internet banking portal service quality and customer satisfaction towards bank dimensions were 0.659 and 0.796 respectively (see Table 2), suggesting good internal consistency among items within each construct and the reliability of the constructs. Reliability for Overall internet banking portal service quality and Customers overall satisfaction towards the bank dimensions was measured using Cronbach's alpha and it is given in Table 2 below: 
Table 2: Reliability Analysis for Overall Internet Banking Portal Service Quality and Customers Overall Satisfaction toward the Bank Dimensions

\begin{tabular}{|l|l|}
\hline Dimensions Name & Cronbach's Alpha Value \\
\hline Overall internet banking portal service quality & 0.659 \\
\hline Customers overall satisfaction toward the bank & 0.796 \\
\hline
\end{tabular}

\subsubsection{Assessment of Validity:}

Validity is an extent to which research is accurate. The validity of a scaling procedure implies that the data must be unbiased and related to the construct being measured. Here, validity was measured using content validity, convergent validity, and discriminant validity.

\section{- Content Validity:}

The degree to which the measure spans the domain of the construct's theoretical definition is defined as the construct's content validity (Rungtusanatham, 1998; Sharma and Halvadia, 2015). Overall internet banking portal service quality and customer satisfaction towards bank dimensions were identified from literature and statements for measuring these dimensions were reviewed by professionals of the banking sector and academicians of the marketing area.

\section{- Convergent Validity:}

There are mainly three methods to measure convergent validity and these methods are factor loading, average variance extracted, and construct reliability (Hair et al., 2007; Halvadia and Halvadia, 2018).For the model given in figure 8, convergent validity was measured using analysis of factor loading, average variance extracted, and construct reliability. In the case of high convergent validity, high loading on a factor would indicate that they converge on some common point and factor loading more than 0.5 indicates good convergent validity (Hair et al., 2007; Sharma and Halvadia, 2015).The factor loading values of all the items of the overall internet banking portal service quality and customers' overall satisfaction toward the bank scales are given in the following table 3. The values of factor loading for all the items are near to or greater than 0.5 and it indicates good convergent validity of the scales. Hair et al. (2007) noted that convergent validity can also be determined by calculating the average variance extracted (AVE) value of the construct. AVE should be near or above 0.5 to indicate convergent validity. Table 3 shows that AVE values of overall internet banking portal service quality and customers' overall satisfaction toward the bank were near or above 0.5 indicating strong convergent validity. Reliability is also an indicator of convergent validity. Construct reliability value (CR) is often used in conjunction with structural equation modeling. High construct reliability indicates that internal consistency exists, meaning that all measures consistently represent the same latent construct. The rule of thumb for construct reliability estimate is that 0.7 or higher suggests good construct reliability. Table 3 shows that for both constructs related to the model given in figure 1 construct reliability is greater than 0.7 and it indicates good construct reliability. 
Table 3: Factor Loading, AVE and CR values for Customers overall satisfaction toward the Bank and Overall Internet Banking Portal Service Quality Dimensions

\begin{tabular}{|c|c|c|c|c|}
\hline $\begin{array}{c}\text { Name of } \\
\text { Dimensions }\end{array}$ & Symbol of Dimension & $\begin{array}{l}\text { Factor } \\
\text { Loading }\end{array}$ & AVE & $\mathbf{C R}$ \\
\hline \multirow{4}{*}{$\begin{array}{l}\text { Customers overall } \\
\text { satisfaction toward } \\
\text { the bank }\end{array}$} & $\begin{array}{l}\text { CS1: Overall, I am satisfied with my } \\
\text { experience with this bank's service. }\end{array}$ & 0.759 & \multirow[t]{4}{*}{0.50} & \multirow[t]{4}{*}{0.70} \\
\hline & $\begin{array}{l}\text { CS2: Overall, I am satisfied with the } \\
\text { internet-based transaction with this } \\
\text { bank. }\end{array}$ & 0.745 & & \\
\hline & $\begin{array}{l}\text { CS3: Overall, I am satisfied with the } \\
\text { products/services offered by this bank. }\end{array}$ & 0.665 & & \\
\hline & $\begin{array}{l}\text { CS4: Overall, I am satisfied with this } \\
\text { bank. }\end{array}$ & 0.639 & & \\
\hline \multirow{2}{*}{$\begin{array}{l}\text { Overall internet } \\
\text { banking portal } \\
\text { service quality }\end{array}$} & $\begin{array}{l}\text { OSQ1: Overall, the service quality of } \\
\text { this internet banking portal is excellent. }\end{array}$ & 0.600 & \multirow[t]{2}{*}{0.52} & \multirow[t]{2}{*}{0.71} \\
\hline & $\begin{array}{l}\text { OSQ2: Overall, this internet banking } \\
\text { portal comes up to my expectation. }\end{array}$ & 0.829 & & \\
\hline
\end{tabular}

\section{Discriminant Validity:}

Discriminant validity is assured if a measure does not correlate very highly with other measures from which it is supposed to differ (O'Leary-Kelly and Vokurka, 1998; Halvadia and Halvadia 2018; Halvadia and Patel,2019). Accordingly to Fornell and Larcker (1981), discriminant validity is established if the AVE is larger than the squared of the correlation coefficient of each construct. From table 4 it can be concluded that overall internet banking portal service quality and customers overall satisfaction toward the bank dimensions supported discriminant validity.

Table 4: Discriminant Validity Analysis for Customers Overall Satisfaction toward the Bank and Overall Internet Banking Portal Service Quality Dimensions

\begin{tabular}{|l|lr|l|}
\hline & $\begin{array}{l}\text { Overall Internet } \\
\text { Banking Portal } \\
\text { Service Quality }\end{array}$ & $\begin{array}{l}\text { Customers } \\
\text { Satisfaction toward the Bank }\end{array}$ \\
\hline $\begin{array}{l}\text { Overall Internet Banking } \\
\text { Portal Service Quality }\end{array}$ & $\mathbf{0 . 5 2}$ & $\mathbf{0 . 5}$ \\
\hline $\begin{array}{l}\text { Customers Overall } \\
\text { Satisfaction toward the } \\
\text { Bank }\end{array}$ & 0.433 & \\
\hline
\end{tabular}




\subsubsection{Path Analysis:}

Path analysis was performed to study the relationship between overall internet banking portal service quality andcustomers' overall satisfaction toward the bank. As we can see from table 5, the path from overall internet banking portal service quality to customers' overall satisfaction toward the bank was significant at a 99\% confidence level ( $p$-value < 0.01). In addition, the standardized coefficient between overall internet banking portal service quality to customer satisfaction towards banks was positive. So, It can be concluded that overall internet banking portal service quality has a positive impact on customers' overall satisfaction toward the bank.

Table 5: Path Analysis for Customers Overall Satisfaction toward the Bank and Overall Internet Banking Portal Service Quality Dimensions

\begin{tabular}{|l|l|l|l|l|l|l|}
\hline \multicolumn{2}{|l|}{ Path } & $\begin{array}{l}\text { Standardized } \\
\text { Regression } \\
\text { Weight }\end{array}$ & Estimate & C.R. & P \\
\hline $\begin{array}{l}\text { Customers overall } \\
\text { satisfaction toward } \\
\text { the bank }\end{array}$ & $<---\begin{array}{l}\text { Overall } \\
\text { internet } \\
\text { banking } \\
\text { portal } \\
\text { service } \\
\text { quality }\end{array}$ & 0.43 & 0.744 & 5.881 & 0.000 \\
\hline
\end{tabular}

\section{Conclusion and managerial implication:}

Structural equation modeling was conducted to measure the impact of overall internet banking portal service quality on customers' overall satisfaction toward the bank. It was found that overall internet banking portal service quality has a positive impact on customers' overall satisfaction toward the bank. Studies carried out in a variety of countries illustrate that internet banking service quality influence customer satisfaction with banking overall (Curry and Penman, 2004; Partricio et al., 2003; Yang and Fang, 2004; Halvadia and Patel,2013). Han and Baek (2004) explored the relationships among customer satisfaction andinternet banking service quality; and found a positive relationship between the level of internetbanking service quality and customer satisfaction.

Similarly, items measuring internet overall internet banking portal service quality and customers overall satisfaction toward the bank were tested and refined. The reliable and valid instrument confirmed in this research can be used by further studies detecting the relationships among these constructs in an extended context. 


\section{References:}

Bauer, H., \&Hammerschmidt, M. (2002). Financial portals in the internet. Proceedings of the WSEAS Conference on E-Commerce, Athens.

Cronbach, L. J. (1951). Coefficient alpha and the internal structure of tests. Psychometrika, 16(1), 297-334.

Curry, B. \&Moutinho, L. (1993). Neural networking in marketing: modelling consumer response to advertising stimuli. European Journal of Marketing, 27(7), 5-20.

Dabholkar, P., \&Bagozzi, R. (2002). An attitudinal model of technology-based self-service: moderating effects of consumers' traits and situational factors. Journal of Academy of Marketing Science. 30(3), 184-201.

Fornell, C., \& Larker, D. (1981). Evaluating structural equation models with unobserved variables and Measurement errors. Journal of Research Marketing, 27(3), 445-466.

Hair,J. F., Black, W. C., Babin, B. J., Anderson, R. E., \& Tatham, R. L. (2007). Multivariate Data Analysis (6th Ed.). Person Education, India.

Halvadia, N. \& Halvadia, S. (2018). Content Analysis for Internet Banking Portal Service Quality Dimensions (September 30, 2018). International Journal of Research in Engineering, IT and Social Sciences, 8(9), 217-226. Available at SSRN: https://ssrn.com/abstract=3375597

Halvadia, N. \& Patel, S. (2013). A Study on Impact of Perceived Risk and Online Trust on Attitude towards Internet Banking Usage in India (January 20, 2013). Consumer Behaviour and Emerging Practices in Marketing. ISBN Number: 978-93-5097-447-6. Available at SSRN: https://ssrn.com/abstract=3375889 or http://dx.doi.org/10.2139/ssrn.3375889.

Halvadia, N. \& Patel, S. (2019). Online Service Quality: Scale Development and Validation. Global Journal of Research in Management, 9(1), 62-83.Available at SSRN: https://ssrn.com/abstract=3517233 or http://dx.doi.org/10.2139/ssrn.3517233. 
Han, S. ,\&Baek, S. (2004). Antecedents and consequences of service quality in online banking: an application of the SERVQUAL instrument. Advances in Consumer Research, 31(1), 208-214.

Ives, B., \& Olson, M. H. (1984). User involvement and MIS success-A review of research. Management Science, 30(5), 586-603.

Jayawardhena, C. (2004). Measurement of service quality in internet delivered services: the development and validation of an instrument. Journal of Marketing Management, 20(1), 185209.

Jun, M., \& Cai, S. (2001). The key determinants of internet bank service quality: a content analysis. International Journal of Bank Marketing, 19(7), 276-291.

McKinney, V., Yoon, K., \& Zahedi, F. (2002). The measurement of web-customer satisfaction: an expectation and disconfirmation approach. Information System Research, 13(3), 296-315.

O’Leary-Kelly, S. W., \&Vokurka, R. J. (1998). The empirical assessment of construct validity, Journal of Operations Management, 16(1), 387-405.

Partricio, L., Fisk, R. P., \& Cunha, J.F. (2003). Improving satisfaction with bank service offerings: measuring the contribution of each delivery channel. Managing Service Quality, 13(6), 471-82.

Rod, M., Ashill, N. J., Shao, J., \& Carruthers, J. (2009). An examination of the relationship between service quality dimensions, overall internet banking service quality and customer satisfaction: A New Zealand study. Marketing Intelligence and Planning, 27(1), 103-126.

Rungtusanatham, M. J. (1998). Let's not overlook content validity. Decision Line, 29(4), 10-13.

Sharma, M. S. \& Halvadia, N. B. (2015). Measuring Service Quality of Internet Banking Portal in India," Annals of Management Science, 4(2), 29-52.Available at: https://digitalscholarship.tnstate.edu/ams/vol4/iss2/2 
Sohail, M. S., \& Shaikh, N. M. (2007). Internet banking and quality of service: Perspectives from a developing nation in the Middle East. Online Information Review, 32(1), 58-72.

Yang, Z., \& Fang, X. (2004). Online service quality dimensions and their relationships with satisfaction: a content analysis of customer reviews of securities brokerage services. International Journal of Service Industry Management, 15(3), 302-326.

Yang, Z., Cai, S., Zhou, Z., \& Zhou, N. (2005). Development and validation of an instrument to measure user perceived service quality of information presenting web portals. Information and Management, 42(1), 575-589.

Zhu, F., Jr, W., \& Chen, I. (2002). IT-based services and service quality in consumer banking. International Journal of Service Industry Management, 13(1), 69-90. 